Article

\title{
Investigating Behavior of Six Methods for Sediment Transport Capacity Estimation of Spatial-Temporal Soil Erosion
}

\author{
Linh Nguyen Van ${ }^{1}$, Xuan-Hien Le ${ }^{2,3}{ }^{\infty}$, Giang V. Nguyen ${ }^{1}$, Minho Yeon ${ }^{1}{ }^{\mathbb{D}}$, Sungho Jung ${ }^{1}$ and Giha Lee ${ }^{1, *}$ \\ 1 Department of Advanced Science and Technology Convergence, Kyungpook National University, \\ 2559 Gyeongsang-daero, Sangju 37224, Korea; linhnguyen@knu.ac.kr (L.N.V.); giangnv@knu.ac.kr (G.V.N.); \\ alsgh2620@knu.ac.kr (M.Y.); sh1202@knu.ac.kr (S.J.) \\ 2 Disaster Prevention Emergency Management Institute, Kyungpook National University, \\ 2559 Gyeongsang-daero, Sangju 37224, Korea; hienlx@knu.ac.kr \\ 3 Faculty of Water Resources Engineering, Thuyloi University, 175 Tay Son, Dong Da, Hanoi 100000, Vietnam \\ * Correspondence: leegiha@knu.ac.kr; Tel.: +82-10-4057-5032
}

Citation: Van, L.N.; Le, X.-H.; Nguyen, G.V.; Yeon, M.; Jung, S.; Lee, G. Investigating Behavior of Six Methods for Sediment Transport Capacity Estimation of SpatialTemporal Soil Erosion. Water 2021, 13, 3054. https://doi.org/10.3390/ w13213054

Academic Editor: Giuseppe Bombino

Received: 6 September 2021

Accepted: 29 October 2021

Published: 1 November 2021

Publisher's Note: MDPI stays neutral with regard to jurisdictional claims in published maps and institutional affiliations.

Copyright: (c) 2021 by the authors. Licensee MDPI, Basel, Switzerland. This article is an open access article distributed under the terms and conditions of the Creative Commons Attribution (CC BY) license (https:// creativecommons.org/licenses/by/ $4.0 /)$.

\begin{abstract}
Estimation of sediment transport capacity (STC) plays a crucial role in simulating soil erosion using any physics-based models. In this research, we aim to investigate the pros and cons of six popular STC methods (namely, Shear velocity, Kilinc-Richardson (KR), Effective stream power, Slope and unit discharge, Englund-Hansen (EH), and Unit stream power) for soil erosion/deposition simulation at watershed scales. An in-depth analysis was performed using the selected STC methods integrated into the Grid Surface Subsurface Hydrologic Analysis model for investigating the changes in morphology at spatial-temporal scales at the Cheoncheon watershed, South Korea, over three storm events. Conclusions were drawn as follows. (1) Due to the ability of the KR and EH methods to include an additional parameter (i.e., erodibility coefficient), they outperformed others by producing more accurate simulation results of sediment concentration predictions. The KR method also proved to be superior to the EH method when it showed a more suitable for sediment concentration simulations with a wide range of sediment size and forcing magnitude. (2) We further selected 2 STC methods among the 6 methods to deeply explore the spatial distribution of erosion/deposition. The overall results were more agreeable. For instance, the phenomenon of erosion mainly occurred upstream of watersheds with steep slopes and unbalanced initial sediment concentrations, whereas deposition typically appeared at locations with flat terrain (or along the mainstream). The EH method demonstrated the influence of topography (e.g., gradient slope) on accretionary erosion/deposition results more significantly than the KR method. The obtained results contribute a new understanding of rainfall-sediment-runoff processes and provide fundamental plans for soil conservation in watersheds.
\end{abstract}

Keywords: sediment transport capacity; rainfall-runoff; erosion; deposition; GSSHA

\section{Introduction}

Soil loss is a severe problem worldwide causing poor water quality, ecosystem destruction, reduced reservoir storage, and decreased agricultural productivity. The process of soil loss comprises the correlated subprocesses of sediment detachment, transportation, and erosion/deposition caused mainly by rainfall impacts and surface flow [1]. Detachment estimation and net deposition are decided by comparing sediment load with sediment transport capacity (STC). Sufficiently high energy must be available to evacuate a soil particle since it has been detached; otherwise, the particle deposits. As a pivotal input function of physics-based soil erosion models, the STC of overland flow is the maximal equilibrium sediment load that surface runoff can convey for specific hydraulic conditions [2,3]. The above-mentioned environmental impacts of soil erosion have persuaded researchers to develop physics-based and computational models that can simulate the effects of sediment movement. Various physics-based models are accessible for soil loss 
simulation, such as HYPE (Hydrological Predictions for the environment) [4], EUROSEM (European Soil Erosion Model) [5], EROSION-3D [6], SHETRAN (SystemeHydrologique Europian-Transport) [7], RUSLE2 (Revised Universal Soil Loss Equation Version 2) [8], and SSEM (Surface Soil Erosion Model) [9].

The STC is influenced by sediment properties and hydraulic conditions. Thus, the performance of each transport capacity formula may vary in various ranges of slope steepness, stream flow, and surface conditions [10,11]. Many scholars have made ceaseless efforts to reveal the influences of different hydraulic variables (e.g., mean flow velocity and stream power) on STC [12-16]. Various materials and techniques have been applied to evaluate the STC by using datasets extracted from flume experiments. Everaert [17] experimented with different types of flumes to uncover empirical relationships between sediment discharge, slope, velocity, and shear velocity. As a result, the author derived four empirical transport capacity formulas based on the median diameter of sediments used in artificial experiments. Sediment characteristics, such as the size and density of sediment particles, are salient components affecting STC [18-21]. Numerous studies have been conducted to uncover the correlation between STC and sediment size [22-25]. Sediment size distribution has a considerable effect on sediment transport and deposition, and more than $40 \%$ of eroded particles are classified as sand [25]. Vegetation cover can also affect STC simulation [3,26,27].

Various STC methods have been developed from river flow conditions [28-31]. Owing to the difference in hydraulic conditions in surface-flow and stream-flow, the application of stream flow functions to surface flow conditions should be questionable. Flow depth and slope gradient, for example, are notable discrepancies between streamflow conditions and surface-flow [32]. Kilinc and Richardson [33], however, concluded that some STC methods for rivers can be applied as surface flow formulas with additional calibration of parameters for a given specific research area. Different researchers have also tested the feasibility of numerous river-flow and surface-flow transport capacity formulas for surface-flow conditions [32,34]. However, none of the research had the same conclusions. Abrahams et al. [14] established an overland-flow transport capacity using a restricted range of flume experimental datasets. The Unit stream power (USP) method was a reliable predictor in simulating STC for overland flow [21,35]. Govers [36] implied that theories of stream power are efficient to estimate STC within a specific range of sediment sizes.

The Grid Surface Subsurface Hydrologic Analysis (GSSHA) model is also one of the physics-based models universally used to calculate sediment concentrations [37]. Prior studies stated that this model is capable of providing reliable hydrological simulations, especially flood peaks [38-41]. However, those studies neglected to stress its ability of erosion/deposition simulation.

Numerous STC methods have been developed and proved their effectiveness in studies on soil erosion. However, there are limited studies that deal with in-depth investigations of their effect on spatial-temporal soil erosion, and the pros and cons of each STC method. Therefore, it is of interest to better understand how the performance of existing STC methods differs in studies of soil erosion/deposition. The purposes of this paper are to (1) investigate the performance of six different methods for STC estimation (e.g., Kilinc-Richardson (KR), Englund-Hansen (EH), Slope and unit discharge (SUD), Shear velocity (SV), USP, and Effective stream power (ESP)) that are incorporated into the GSSHA model and (2) to analyze the effect of those methods on the spatial-temporal distribution of soil erosion. The Cheoncheon basin (a sub-basin of Yongdam Dam basin in South Korea) was chosen as a study site in this study. Three different storm events are used to uncover the model to rainfalls, and the performance of the model is assessed by statistical indicators. The obtained results contribute to a new understanding of rainfall-runoff-sediment processes and provide fundamental plans for soil conservation in watersheds. 
The schematic diagram of the study is illustrated in Figure 1 and the structure of the paper is designed as follows. Section 2 provides general information about the study site and input data. Methodologies of 6 STC methods and model description/setup are presented in Section 3. Rainfall-runoff-sediment evaluations, the spatial distribution of soil erosion/deposition, and the effect of topography on spatial distribution are visualized and analyzed in Section 4, followed by summarized conclusions in Section 5.

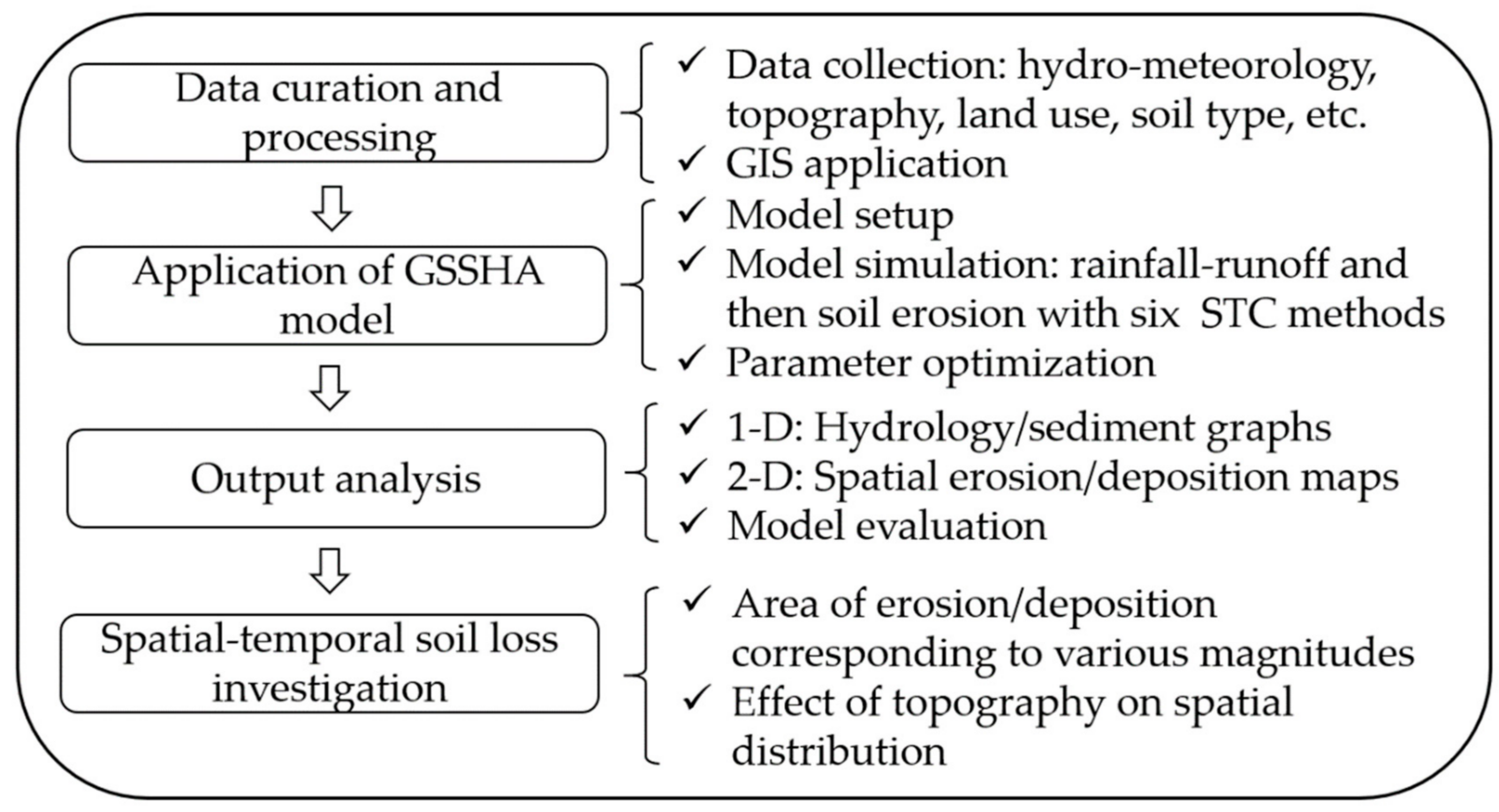

Figure 1. The schematic diagram of the study.

\section{Study Area and Data Availability}

The Cheoncheon basin is located in the upper part of the Yongdam dam basin (Figure 2). With the area corresponding to $290.1 \mathrm{~km}^{2}$ the sub-basin contains approximately $31 \%$ of the Yongdam dam catchment. The Cheoncheon basin is the main inflow supply into the Yongdam Dam which contributes up to 74\% of the total inflow [42]. Korean water resources company (K-water) has selected the Cheoncheon basin as an experimental site to evaluate water quantity and quality. The watershed is mainly characterized by a hilly topography with elevation ranging from 277 to $1452 \mathrm{~m}$ (Figure 3c). The parent materials are mainly dominated by acidic rocks and metamorphic rocks. The main stream is approximately $28 \mathrm{~km}$ long with an average slope of $0.246 \mathrm{~m} / \mathrm{m}$. The annual average temperature and humidity are $14{ }^{\circ} \mathrm{C}$ and $74 \%$, respectively. Rainfall seasons with high intensity occur at the site between July to August, accounting for approximately half of the total annual rainfall.

Land use/land cover (LULC) information about the study area was extracted from cloud-free Landsat ETM+ image on November 22, 2002 (Path 115, Row 035) and processed via the ArcGIS 10.5 software using a Maximum-likelihood-classifier. As shown in Figure 3a, the classification output depicted the distribution of six categories, including the preeminence of mixed forest (63\% of the basin) and mixed field (22\%). The soil type data is extracted from National Soil Survey Projects [43]. The soil survey project had started in 1964 with a 1:250,000 Korean soil map as a result. After various phases, the final highly detailed digital soil maps (1:5000) product has been published online in http://soil.rda.go.kr/ (accessed on 8 August 2021). Two main techniques 
had been applied to determine soil texture including textural analysis in the laboratory and feel method in the field. The soil properties are illustrated in Table 1. Soil types in this study area are dominated by Oesan (19\%) and Samgag (39\%) (Figure 3b). Based on the percentages of sand, silt, and clay in the soil and the USDA soil taxonomy [44], the prevailing soil types in this study are classified into silty loam and sandy loam, respectively. In the study of Sastre et al. [45], the authors stated that silty loam texture was highly susceptible to causing erosion. The DEM displays cartographic information. Advanced Spaceborne Thermal Emission and Reflection Radiometer (ASTER) with 30-m resolution was used to draw the basin, extract information about the Cheoncheon topography through WMS watershed delineator tools.

Hourly rainfall data for three storm events was obtained from Water Resources Management Information System, South Korea. Those events were historical events that happened in 2002, 2003, and 2007. The characteristics of three events are shown in Table 2. Four meteorological stations and a hydrological station were utilized in this study. Two meteorological stations are located outside the Cheoncheon basin. For model calibration/validation, the observation of flow and sediment discharge at the outlet were extracted from regression equation curves (Table A1) [46-48]. Table 3 summarizes information about the data presented in this study.

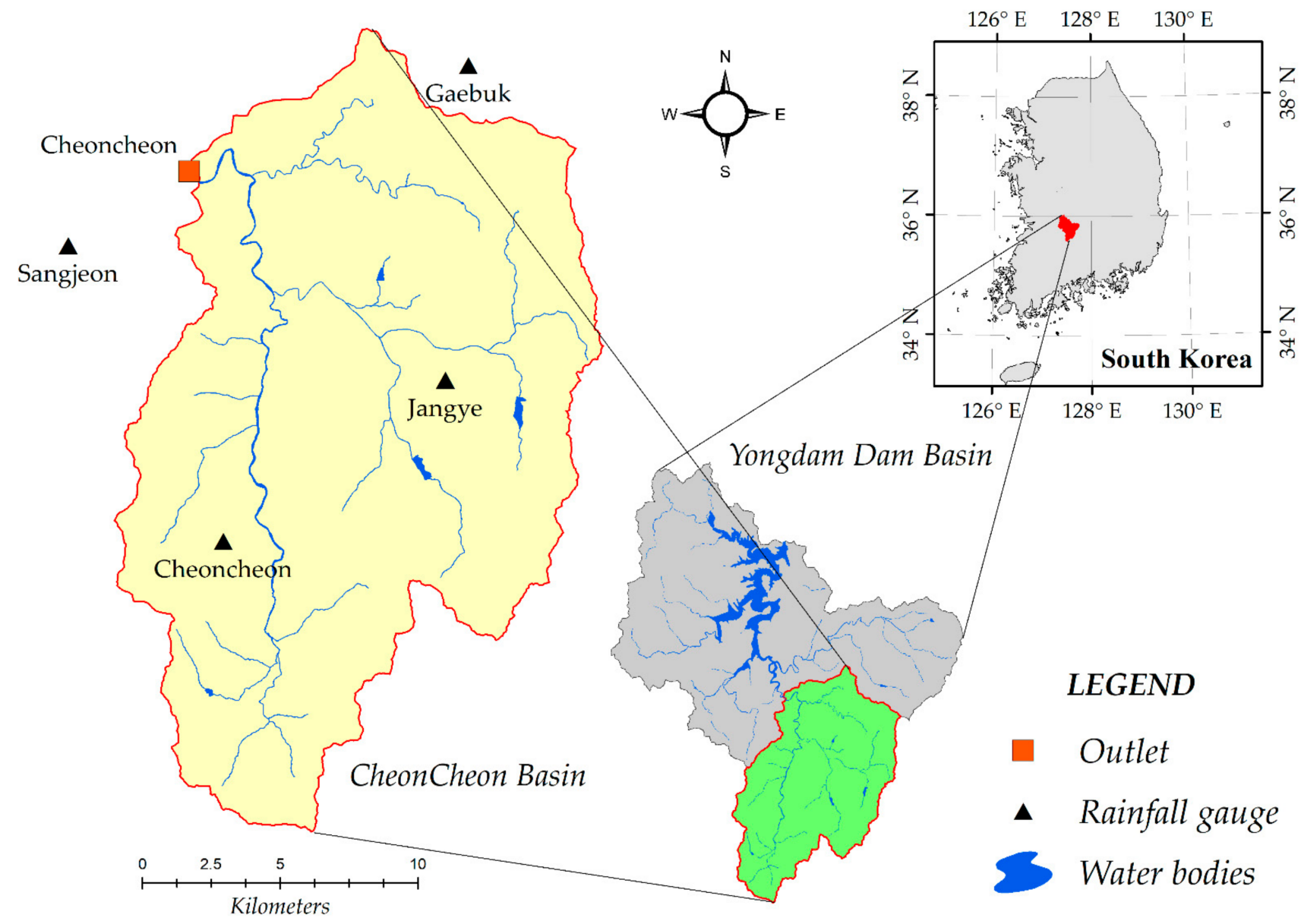

Figure 2. Location of the Cheoncheon watershed. 


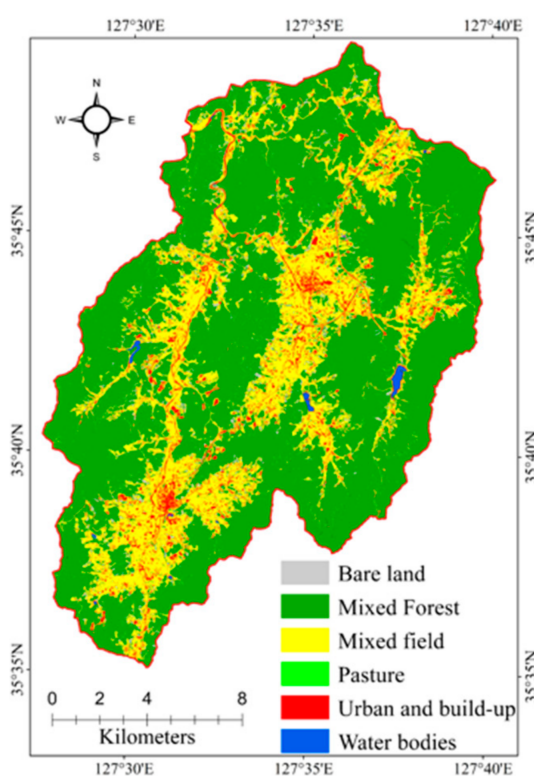

(a)

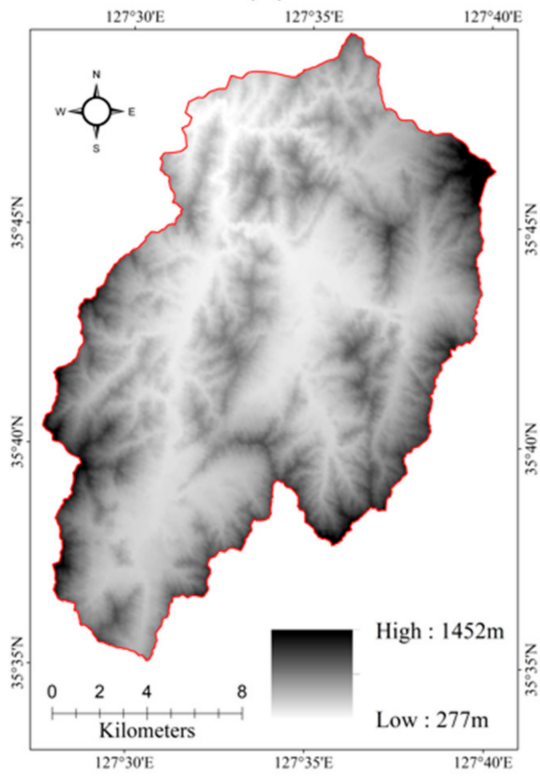

(c)

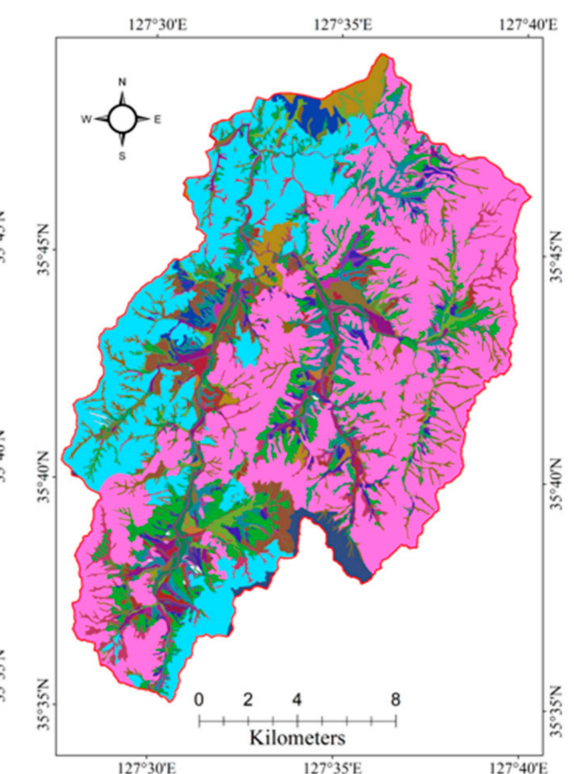

(b)

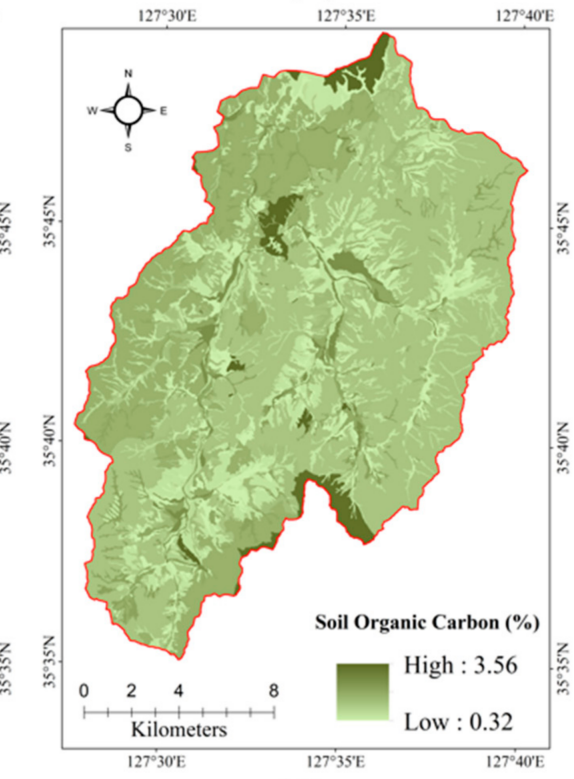

(d)

\section{Soil Type}

\begin{tabular}{|c|c|}
\hline ANRYONG & $\square O E S A N$ \\
\hline CHILGOG & $\square O S A N$ \\
\hline$D E O G P Y E O N G$ & - PUNGCHEON \\
\hline$\square$ DEOGSAN & $\square R C S$ \\
\hline EUNGOG & Rock Outcrop \\
\hline GACHEON & $\square$ SACHON \\
\hline GOPYEONG & $\square S A M A M$ \\
\hline GWANAG & $\square S A M G A G$ \\
\hline - HAMO & $\square S A N G J U$ \\
\hline$\square$ HOEGOG & $=S E O G T O$ \\
\hline HOGYE & - SEONGIN \\
\hline HWADONG & - SONGSAN \\
\hline WWANGRYONG & $\square$ SUAM \\
\hline$I M G O G$ & $\square U G O G$ \\
\hline -JANGGYE & WEOLGOG \\
\hline JIGOG & Water \\
\hline$\square A E G O G$ & $\square$ YECHEON \\
\hline NAMGYE & - YESAN \\
\hline$=O D A E$ & $\square$ YONGGYE \\
\hline
\end{tabular}

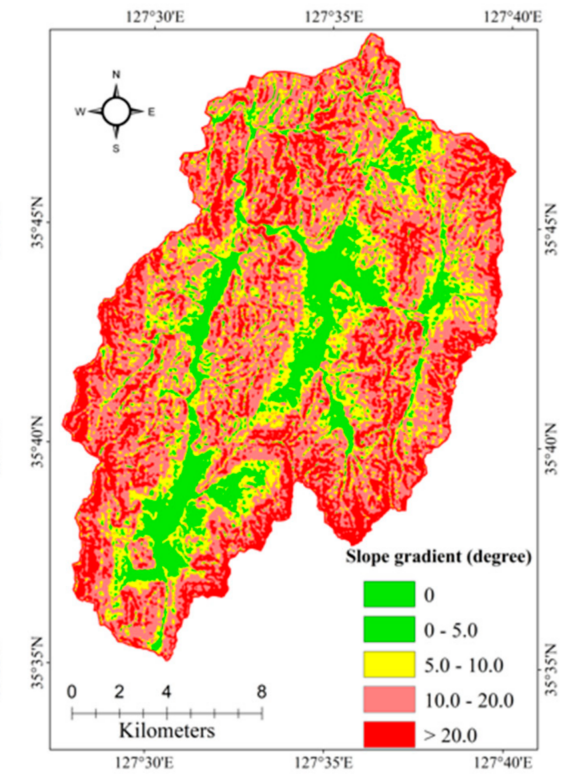

(e)

Figure 3. (a) Land use type; (b) Soil type; (c) DEM; (d) Soil organic carbon; (e) Slope gradient.

Table 1. Particle-size properties for the study.

\begin{tabular}{ccc}
\hline Description & Particle Diameter $(\mathbf{m m})$ & Particle Size Distribution (\%) \\
\hline Very coarse sand & 1.45 & \\
Coarse sand & 0.65 & \\
Medium sand & 0.37 & Table A2 \\
Fine sand & 0.17 & \\
Very fine sand & 0.08 & \\
Coarse silt & 0.03 & \\
Fine silt & 0.011 & \\
Clay & 0.003 & \\
\hline
\end{tabular}


Table 2. Description of three storm events.

\begin{tabular}{ccccccc}
\hline Event Number & $\begin{array}{c}\text { Total Duration } \\
\text { (Hour) }\end{array}$ & $\begin{array}{c}\text { Total Rainfall } \\
(\mathbf{m m})\end{array}$ & $\begin{array}{c}\text { Peak Rainfall } \\
(\mathbf{m m})\end{array}$ & Number of Peaks & Name of Events & Description \\
\hline 1 & 75 & 194.8 & 27 & 1 & Rusa & Calibration \\
2 & 92 & 133.9 & 26 & 2 & Maemi & Validation \\
3 & 178 & 205.5 & 48 & 2 & Nari & Validation \\
\hline
\end{tabular}

Table 3. Information about the data used in this study.

\begin{tabular}{|c|c|c|}
\hline Data Layer & Description & Data Source \\
\hline Meteorological data & Hourly precipitation & $\begin{array}{l}\text { Water Resources Management Information System } \\
\text { (http://wamis.go.kr/) }\end{array}$ \\
\hline Soil type data & & $\begin{array}{c}\text { Korean Soil Information System } \\
\text { (http: / / soil.rda.go.kr/) }\end{array}$ \\
\hline $\begin{array}{l}\text { Land use/land cover data } \\
\text { DEM data }\end{array}$ & $30 \times 30 \mathrm{~m}$ resolution & $\begin{array}{l}\text { NASA's EarthExplorer web service } \\
\text { (http:/ / earthexplorer.usgs.gov/) }\end{array}$ \\
\hline
\end{tabular}

\section{Methodology}

\subsection{Six Methods for Sediment Transport Capacity Estimation}

Firstly, Kilinc and Richardson [33] investigated soil erosion behavior from surface flow by using an artificial rainfall system at the Engineering Research Center of Colorado State University. The initial KR equation was developed for sand-size particles and then was modified by Julien [49] in 1995 to simulate smaller particles. In 2001, Orden and Heilig [50] advocated for the final version (Equation (1)) to include a reduction parameter for use at event scales.

$$
\mathrm{T}_{\mathrm{c}}=25,500 \mathrm{q}^{2.035} \mathrm{~S}_{\mathrm{f}}^{1.664} \frac{\mathrm{K}}{0.15}
$$

where $T_{c}$ represents the sediment unit discharge (ton $\mathrm{m}^{-1} \mathrm{~s}^{-1}$ ), $\mathrm{q}$ represents the unit discharge $\left(\mathrm{m}^{-1} \mathrm{~s}^{-1}\right), \mathrm{S}_{\mathrm{f}}$ represents the friction slope (unitless), and $\mathrm{K}$ represents the erodibility factor. The $\mathrm{K}$ ranges from 0 to 1 and is used as a calibration parameter.

Secondly, Equation (2) was developed by Englund and Hansen and based on flume data and sediment size of bed material as input variables [28]. Equation (2) is to calculate the transport rate in total by multiplying the percentage of each soil particle size fraction (e.g., sand, silt, clay):

$$
P_{i}=K F_{j} \frac{0.05 B V^{2} h^{1.5} S_{f}^{1.5}}{(s-1)^{2} D_{j} \sqrt{g}}
$$

where $P_{i}$ represents the volumetric sediment transport rate of i-th size fraction $\left(\mathrm{m}^{3} \mathrm{~s}^{-1}\right)$, $F_{j}$ represents the proportion of $\mathrm{j}$-th faction in the layer $(0-1)$, B represents the flow width $(\mathrm{m}), \mathrm{V}$ represents the mean water velocity $\left(\mathrm{m} \mathrm{s}^{-1}\right), \mathrm{h}$ represents the flow depth $(\mathrm{m}), \mathrm{s}$ represents the specific gravity of $\mathrm{j}$-th fraction (unitless), g represents the gravitational acceleration $\left(\mathrm{m} \mathrm{s}^{-1}\right)$, and $D_{j}$ represents the mean size of the $j$-th fraction $(\mathrm{m})$.

Thirdly, four STC methods (Equations (3)-(6)) were established by Everaert [17] in relation the of sediments to uncover empirical interrelationships between sediment discharge, slope, velocity, and shear velocity using flumes experiment.

SUD Equation:

$$
\mathrm{T}_{\mathrm{c}}=\mathrm{aS}_{\mathrm{f}}^{\mathrm{b}} \mathrm{q}^{\mathrm{c}}
$$

SV Equation:

$$
\mathrm{T}_{\mathrm{c}}=\mathrm{d}\left(\mathrm{u}_{*}-\mathrm{u}_{* \mathrm{cr}}\right)^{\mathrm{e}}
$$

USP Equation:

$$
\mathrm{T}_{\mathrm{c}}=0.316\left(100 \mathrm{~S}_{\mathrm{f}} \mathrm{V}\right)^{2.59} \mathrm{D}_{50}^{-0.39}
$$


ESP Equation:

$$
\mathrm{T}_{\mathrm{C}}=4.61^{-7} \Omega^{1.75} \mathrm{D}_{50}^{-0.56}
$$

where $T_{c}$ represents the sediment unit discharge $\left(\mathrm{g} \mathrm{cm}^{-1} \mathrm{~s}^{-1}\right)$; $\mathrm{q}$ represents unit discharge $\left(\mathrm{cm}^{2} \mathrm{~s}^{-1}\right) ; \mathrm{u}_{* \mathrm{cr}}$ represents the critical shear velocity $\left(\mathrm{cm} \mathrm{s}^{-1}\right) ; \mathrm{u}^{*}$ represents the actual shear velocity $\left(\mathrm{cm} \mathrm{s}^{-1}\right) ; \Omega$ represents the effective stream power; $a, b, c, d$, and e represent the empirical parameters.

\subsection{Physics-Based Model: GSSHA}

The GSSHA model is a fully distributed, physics-based, and hydrologic model capable of simulating hydrologic processes, water quality analysis, and sediment transport on either event-based or continuous configuration [51]. The GSSHA model is implemented into Watershed Modeling System (WMS) version 11.0 software by Aquaveo, which allows modelers to visualize the model [52]. The model is based on grid-cell structure and uses two-dimensional (2D) diffusive wave equations to calculate surface runoff (e.g., Alternative Direction Explicit (ADE), ADE Predictor-Corrector, and Explicit). The up-gradient explicit method is adopted to simulate one-dimensional channel flow. For infiltration simulation, several approaches (namely, Green and Ampt with soil moisture redistribution, Green and Ampt multilayer, and Richard's infiltration) are applied and integrated into the GSSHA model. Inverse Distance Weighted and Thiessen polygons methods are utilized for spatial distribution of precipitation. Lateral groundwater flow and evapotranspiration (ET) are simulated using 2D vertically averaged and the Penman-Monteith or Deardorff method, respectively. Various auto-calibration methods have been established into the GSSHA model (e.g., Levenberg-Marquardt/Secant LM, Multi-start, Trajectory Repulsion, Multilevel Single Linkage, and Shuffled Complex Evolution (SCE)). The GSSHA model is also a powerful tool for simulating soil erosion/deposition, which involves complicated processes such as detachment by raindrop impact and overland runoff.

Raindrop impact plays an initial role in the detachment and transport of particles. The equation below shows the inter-relationship between rainfall momentum, surface water depth, vegetable cover, and canopy interception [53]:

$$
\mathrm{D}_{\mathrm{R}}=\mathrm{K}_{\mathrm{R}} \mathrm{H}_{\mathrm{W}} \mathrm{C}_{\mathrm{C}} \mathrm{C}_{\mathrm{M}} \mathrm{M}_{\mathrm{R}}
$$

where $D_{R}$ represents the detachment capacity rate $\left(\mathrm{kg} \mathrm{m}^{-2} \mathrm{~s}^{-1}\right), \mathrm{K}_{\mathrm{R}}$ represents the soil erodibility factor by raindrop detachment $\left(\mathrm{J}^{-1}\right), \mathrm{H}_{\mathrm{w}}$ represents the water depth correction factor (unitless), $C_{C}$ represents the canopy cover factor (unitless), $C_{M}$ represents the covermanagement factor (unitless), and $\mathrm{M}_{\mathrm{R}}$ represents the momentum squared for rainfall $\left[\left(\mathrm{kg} \mathrm{m} \mathrm{s}^{-1}\right)^{2} \mathrm{~m}^{-2} \mathrm{~s}^{-1}\right]$.

Soil detachment by surface flow plays a paramount role in soil loss estimation [54]. The philosophy of the detachment depends on a specific threshold using shear stress that destroys the links between soil particles, as follows:

$$
\mathrm{D}_{\mathrm{F}}=\alpha\left(\mathrm{T}-\mathrm{T}_{c}\right)^{\beta}\left(1-\frac{\mathrm{G}}{\mathrm{T}_{\mathrm{c}}}\right)
$$

where $D_{F}$ represents the detachment capacity rate $\left(\mathrm{kg} \mathrm{m}^{-2} \mathrm{~s}^{-1}\right), \alpha$ and $\beta$ represent the empirical coefficients, $\mathrm{T}$ represents the shear stress of flow $(\mathrm{Pa}), \mathrm{T}_{\mathrm{c}}$ represents the critical shear stress $(\mathrm{Pa}), \mathrm{G}$ represents the sediment load $\left(\mathrm{kg} \mathrm{m}^{-2} \mathrm{~s}^{-1}\right)$, and $\mathrm{T}_{\mathrm{c}}$ represents the STC of overland flow $\left(\mathrm{kg} \mathrm{m}^{-2} \mathrm{~s}^{-1}\right)$.

\subsection{Model Setup and Evaluation}

The ArcGIS 10.5 (ESRI) platform [55] was deployed to prepare the necessary input data (e.g., Digital Elevation Model (DEM), LULC, and soil type). To avoid adverse effects resulting from inaccuracies of DEMs, all streams were smoothed and assumed trapezoidal 
in the section. Topographic information is critical for accurate model predictions. A DEM with a resolution of 250-m is a suitable size for distributed rainfall-runoff modeling [56]; thus, the basin was discretized into 5155 computational grids at $250 \times 250$-m resolution The computation time step in the GSSHA model was selected as $30 \mathrm{~s}$. The ADE method was employed for simulating 2D surface flow, whereas the Green and Ampt with soil moisture redistribution was used to describe infiltration. The rainfall pattern was spatially distributed using the Thiessen polygons method application. To optimize nine model parameters reported in Table 4, the SCE method was selected [57]. The initial values of these parameters were referred to literature and GSSHA User's Manual [58]. ET was neglected in storm events for the sake of simplicity.

Table 4. Calibrated parameters used in the GSSHA model for flow discharge prediction.

\begin{tabular}{cccc}
\hline Parameter & Land Use/Soil Type & Range of Values & Optimal Value \\
\hline \multirow{2}{*}{ Surface roughness (manning's n) } & Mixed forest & $0.05-0.6$ & 0.1921 \\
& Mixed field & $0.03-0.2$ & 0.1676 \\
\hline Retention depth $(\mathrm{mm})$ & Mixed forest & $0.1-10.0$ & 5.0739 \\
& Mixed field & $0.1-10.0$ & 6.6658 \\
\hline Hydraulic conductivity $(\mathrm{cm} / \mathrm{h})$ & Oesan & $0.01-3.0$ & 0.0573 \\
\hline Soil moisture depth $(\mathrm{m})$ & Samgag & $0.01-1.0$ & 0.0871 \\
\hline Top layer depth $(\mathrm{m})$ & & $0.1-1.0$ & 0.8948 \\
\hline Channel roughness $(\mathrm{manning}$ 's n) & & $0.03-0.3$ & 0.1197 \\
\hline
\end{tabular}

To evaluate the model's performance, four statistical indicators have been employed (Equations (9)-(12)). Each criterion has its merits and weaknesses. The coefficient of determination $\left(\mathrm{R}^{2}\right)$ provides information about the linear relationship between simulated and predicted values. Ranging between 0.0 and 1.0, a higher value of $R^{2}$ shows less bias-variance. A value higher than 0.5 is acknowledged to be acceptable in hydrological simulations. The Root Mean Square Error (RMSE) ranges from 0.0 to $+\infty$, and in contrast to $\mathrm{R}^{2}$, small RMSE corresponds to a better model. The optimal value of Percent Bias (PBIAS) is 0.0 , ranging from $-\infty$ to $+\infty$. Negative values of PBIAS indicate the overestimation of model performance, whereas positive values imply model underestimation bias [59]. The total bias of the volume is illustrated by Volume Conversation Index (VCI) with the best value corresponding to 1.0 .

$$
\begin{gathered}
\mathrm{R}^{2}=\frac{\left[\sum_{\mathrm{k}=1}^{\mathrm{n}}\left(\mathrm{O}_{\mathrm{k}}-\overline{\mathrm{O}}\right)\left(\mathrm{S}_{\mathrm{k}}-\overline{\mathrm{S}}\right)\right]^{2}}{\sum_{\mathrm{k}=1}^{\mathrm{n}}\left(\mathrm{O}_{\mathrm{k}}-\overline{\mathrm{O}}\right)^{2} \sum_{\mathrm{k}=1}^{\mathrm{n}}\left(\mathrm{S}_{\mathrm{k}}-\overline{\mathrm{S}}\right)^{2}} \\
\text { RMSE }=\sqrt{\frac{1}{\mathrm{n}} \times \sum_{\mathrm{k}=1}^{\mathrm{n}}\left(\mathrm{O}_{\mathrm{k}}-\mathrm{S}_{\mathrm{k}}\right)^{2}} \\
\text { PBIAS }=100 \times \frac{\sum_{\mathrm{k}=1}^{\mathrm{n}}\left(\mathrm{O}_{\mathrm{k}}-\mathrm{S}_{\mathrm{k}}\right)}{\sum_{\mathrm{k}=1}^{\mathrm{n}} \mathrm{O}_{\mathrm{k}}} \\
\text { VCI }=\frac{\sum_{\mathrm{k}=1}^{\mathrm{n}} \mathrm{S}_{\mathrm{k}}}{\sum_{\mathrm{k}=1}^{\mathrm{n}} \mathrm{O}_{\mathrm{k}}}
\end{gathered}
$$

where $\mathrm{O}_{\mathrm{k}}$ and $\mathrm{S}_{\mathrm{k}}$ denote the observed and predicted values, respectively; $\mathrm{n}$ represents the total number of paired values, and $\overline{\mathrm{O}}$ and $\overline{\mathrm{S}}$ denote the average observed and simulated values, respectively. 


\section{Results and Discussion}

\subsection{Rainfall-Runoff Calibration}

The reliability of sediment transport prediction depends on the accuracy of the runoff process. Downer and Ogden [58] suggested that the retention depth, surface roughness, river roughness, soil hydraulic conductivity, soil moisture depth, and the top layer depth are sensitive parameters that should be calibrated in the GSSHA model. As a process-based model, the number of calibrated parameters should be strictly selected to a minimum for robust simulation [60]. The calibrated parameters for estimating flow discharge are listed in Table 4.

Overall, there was a consistent trend of simulated and observed lines of flow discharge in the three events (Figure 4). The coefficient of determination suggested very high correlations for the model. In the calibration procedure, four values of the statistical indicators illustrated high agreement between the observed and simulated flow discharge $\left(\mathrm{R}^{2}=0.90, \mathrm{RMSE}=116.79 \mathrm{~m}^{3} / \mathrm{s}\right.$, PBIAS $=20.17 \%$, and VCI $\left.=0.998\right)$. The compromise between the observation and simulation values gradually decreased during the validation experiments, but was still satisfactory and within the acceptable range (Table 5). Without considering the small rainfall peaks, Event 2 has a more similar rainfall pattern with Event 1 compared to Event 3. This explains why the result of $R^{2}$ from Even $2(0.92)$ is higher than that of Event 3 (0.73). It is also noted that the RMSE result of Event 1 is the highest among the three events. The observation value of peak flow in Event $1\left(1385 \mathrm{~m}^{3} / \mathrm{s}\right)$ is higher than in Event 2 and 3 (932 and $1131 \mathrm{~m}^{3} / \mathrm{s}$, respectively); and the duration of Event 1 is also the shortest (Table 2). This can explain the reason why the RMSE value of the calibration event is higher than that of the validation ones since the RMSE detects the mean of the square bias. The PBIAS results ranging from $20.17 \%$ to $61.47 \%$ in three events indicate that the model tends to underestimate the rainfall-runoff predictions. As a result, the GSSHA model behaved as a potentially robust predictor for flow discharge.

Table 5. Statistical analysis of observed and simulated values of flow discharge.

\begin{tabular}{ccccc}
\hline Event & $\mathbf{R}^{2}$ & RMSE $\left(\mathbf{m}^{\mathbf{3}} / \mathbf{s}\right)$ & PBIAS (\%) & VCI \\
\hline 1 & 0.90 & 116.79 & 20.17 & 0.998 \\
2 & 0.92 & 76.32 & 60.02 & 0.505 \\
3 & 0.73 & 96.67 & 61.47 & 0.385 \\
\hline
\end{tabular}

\subsection{Sediment Transport Evaluation}

Table 6 reports the results of sediment concentrations produced by six STC methods. Overall, the sediment concentration predictions were less accurate than the flow discharge simulations in both calibration and validation tests. During the calibration and validation processes, the sediment concentration prediction was determined to be applicable only with the KR and EH methods. The former and the latter simulated sediment concentrations with acceptable results in the calibration task (Figure 5). The values of $\mathrm{R}^{2}$, RMSE, PBIAS, and VCI obtained by the KR method were $0.82,532.65 \mathrm{~m}^{3} / \mathrm{s}, 20.17 \%$, and 0.798 , respectively. In sequence order, these values were $0.77,599.65 \mathrm{~m}^{3} / \mathrm{s}, 11.55 \%$, and 0.885 for the EH method. The results of $R^{2}$ imply that the linear relationship between simulated and predicted sediment concentrations simulated by the KR method is higher than that of the KR method. However, the PBIAS and VCI indexes show that the latter has less bias in terms of total sediment volume predictions than the former. During the validation experiments, the KR method outperformed the EH method. Detailed values are listed in Table 6. According to Johnson et al. [61], these values are among an acceptable range for sedimentation simulations. For the Everaert methods, minimal values of $R^{2}$ denoted by "-“ pinpointed no linear relationship between simulated and observed values of sediment concentrations. The remaining statistical indicators also illustrated poor performance. 

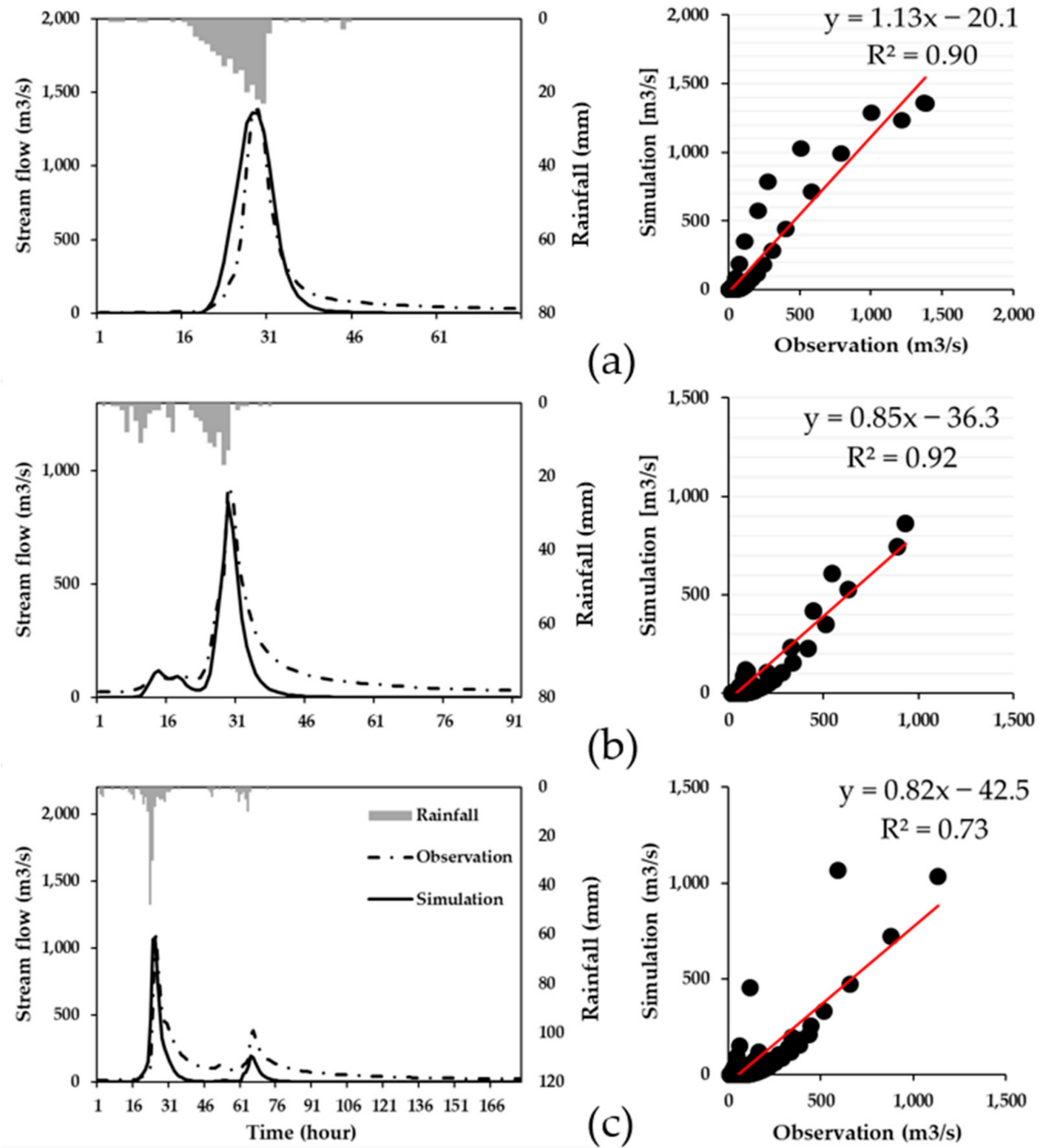

(b)
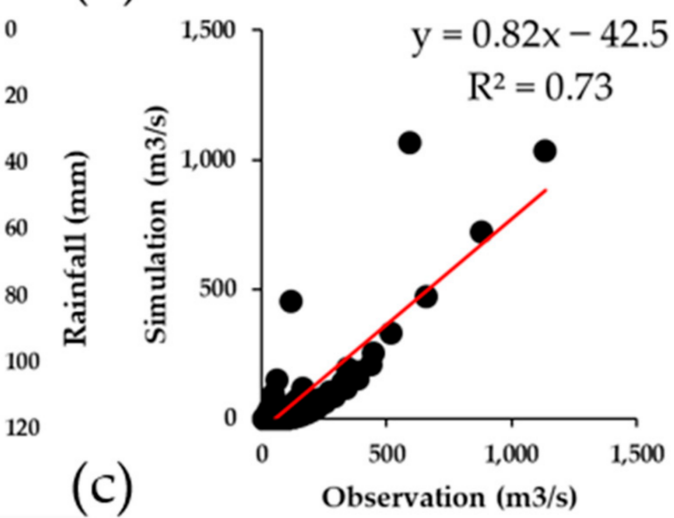

Figure 4. Flow discharge predicted by the GSSHA model in Event 1 (a), Event 2 (b), and Event 3 (c). The scatter plots (and $\mathrm{R}^{2}$ values) represent a 1:1 comparison between the prediction (y-axis) and the observation (x-axis), and the black lines denote the stream discharge.

Table 6. Statistical analysis of observed and predicted values of sediment concentrations.

\begin{tabular}{cccccc}
\hline Method & Event & $\mathbf{R}^{2}$ & RMSE (mg/L) & PBIAS (\%) & VCI \\
\hline \multirow{3}{*}{ KR } & 1 & 0.83 & 532.65 & 20.17 & 0.798 \\
& 2 & 0.80 & 778.63 & 60.12 & 0.401 \\
& 3 & 0.58 & 918.96 & 66.49 & 0.335 \\
\hline \multirow{2}{*}{ EH } & 1 & 0.77 & 599.65 & 11.55 & 0.885 \\
& 2 & 0.75 & 816.76 & 58.79 & 0.412 \\
& 3 & 0.46 & 946.31 & 69.06 & 0.309 \\
\hline \multirow{2}{*}{ USP } & 1 & - & 1193.21 & 96.01 & 0.262 \\
& 2 & - & 1368.87 & 96.66 & 0.033 \\
& 3 & - & 2471.68 & 73.85 & 0.039 \\
\hline
\end{tabular}


Table 6. Cont.

\begin{tabular}{cccccc}
\hline Method & Event & $\mathbf{R}^{2}$ & RMSE (mg/L) & PBIAS (\%) & VCI \\
\hline \multirow{3}{*}{ ESP } & 1 & - & 1293.95 & -0.15 & 1.001 \\
& 2 & - & 1080.04 & 69.27 & 0.307 \\
& 3 & - & 4771.54 & -2.93 & 1.029 \\
\hline \multirow{3}{*}{ SUD } & 1 & - & 203,673 & $-13,235.5$ & 133.35 \\
& 2 & - & 98,484 & -5826.61 & 59.2 \\
& 3 & - & 112,527 & -4852.65 & 49.5 \\
\hline \multirow{2}{*}{ SV } & 1 & - & $12,854,268$ & $-1,249,831$ & 14,342 \\
& 2 & - & $28,149,108$ & $-1,740,866$ & 26,384 \\
& 3 & 1 & $38,661,463$ & $-736,509$ & 34,976 \\
\hline
\end{tabular}

${ }^{1}$ minimal value of $R^{2}$

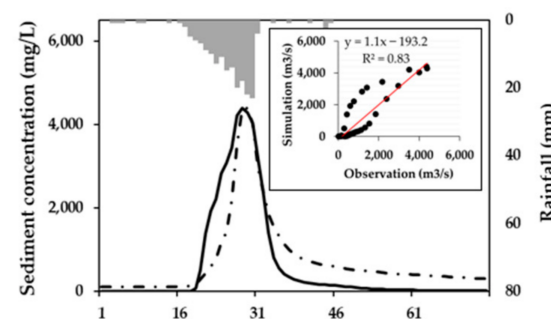

(a)

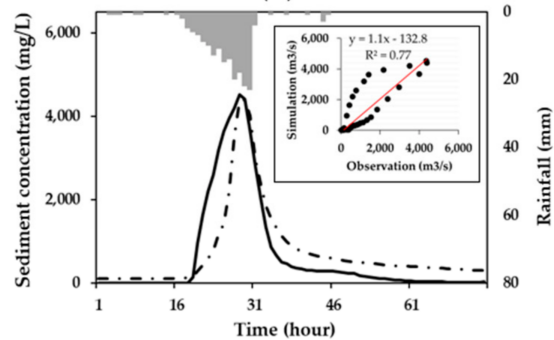

(d)

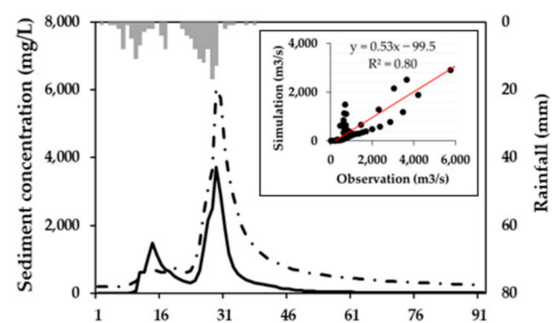

(b)

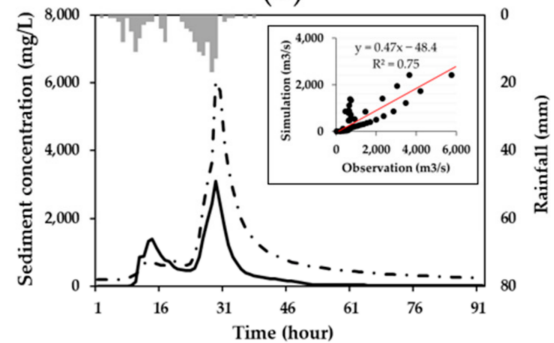

(e)

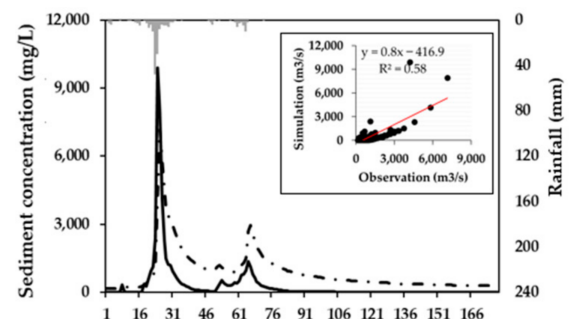

(c)

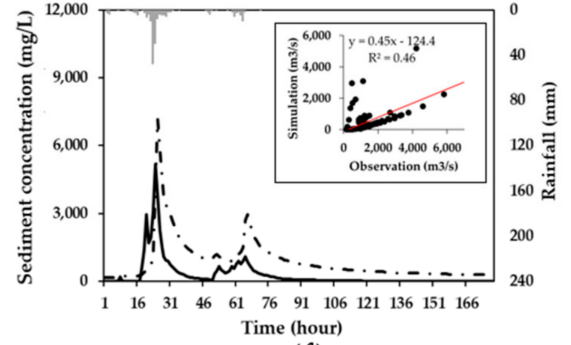

(f)

Rainfall

- - Observation

- Simulation

Figure 5. Comparison between simulation and observation of sediment concentrations in Cheoncheon basin with the KR method in Event 1 (a), Event 2 (b), and Event 3 (c); with the EH method in Event 1 (d), Event 2 (e), and Event 3 (f).

The main reasons for Everaert methods' failure to predict sediment concentration are related to particle size and topography characteristics. On the one hand, the median diameter of grain sizes from Everaert's study varied from 0.033 to $0.39 \mathrm{~mm}$, whereas there is a wider range of grain sizes in the Cheoncheon basin (Table 1). This presents the hypothesis that the Everaert methods could not simulate very fine and coarse textures accurately. The success of stream power theories in STC estimation depends on the grain size of sediment as pivotal input [12]. On the other hand, previous studies had the same agreement that sediment loss and transport capacity are sensitive to the slope gradient $[21,62,63]$. The slopes $\left(0-42.6^{\circ}\right)$ in the Cheoncheon basin are significantly steeper than gentle slopes $\left(<10^{\circ}\right)$ in Everaert's study, and approximately $73 \%$ of the basin has a slope value higher than $10^{\circ}$ (Figure 3e). Zhang et al. [64] indicate that the significant implications of slope gradient trigger the increment in sediment concentrations. This explains the failure estimation of sediment concentrations using the Everaert methods. In the GSSHA model, these formulas had no parameters for calibration tasks and were likely to vanish in the next release version.

The EH method is the only method that originated from stream flow conditions in the six mentioned STC methods. In the calibration task, the performance of the EH equation showed a reasonable agreement between sediment concentration values of observation and 
simulation. The reason probably is that the movement of sand particles in surface runoff situations includes rolling, creeping, sliding, and saltating processes [65], which resemble bedload transport of sand in rivers. The validation periods show a decreasing performance of the EH equation in sediment concentration prediction missions due to the discrepancies in hydraulic conditions between overland flow and stream flow. Surface flow is significantly shallower than river flow, and flow conditions in shallow flows vary temporally owing to surface roughness [66], which depends on the LULC change. The limitation of the study is that uniform LULC has been used in the rainfall-runoff-sediment simulation for three events. This contributes to the declining agreement between observed and simulated values of sediment concentrations. The KR method is robust in predicting sediment concentrations, which agrees with the conclusion of Downer et al. [37]. Experiments conducted by Kilinc and Richardson were similar to the situation in the study watershed with slope gradients ranging up to $22^{\circ}$.

\subsection{Spatial Distribution of Soil Erosion/Deposition}

Owing to the striking performance in sediment concentration predictions, the KR and the EH methods were spatially analyzed in more detail. For the sake of visual simplicity, spatial information about erosion and deposition was detailed by valued-colored grid cells using the ArcGIS platform. Figure 6 displays spatial-temporal variations in erosion/deposition maps predicted by the KR and EH methods. Overall, the two STC methods agreed on the spatial and temporal dissemination of erosion/deposition. Spatially, the erosion pattern was spotted over the watershed, whereas the deposition pattern was mainly distributed along the river networks. The sediment budget results revealed severe sediment detachments form a rill erosion type occurring around the basin boundaries in steep slope zones, particularly in the southeast and northwest of the watershed.

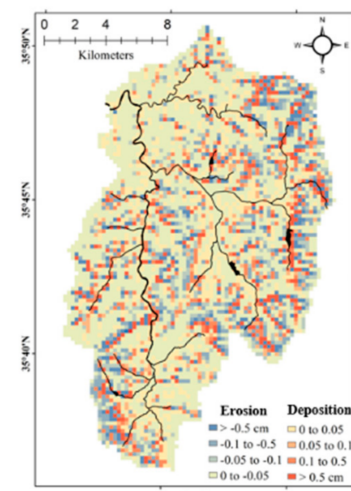

(a)

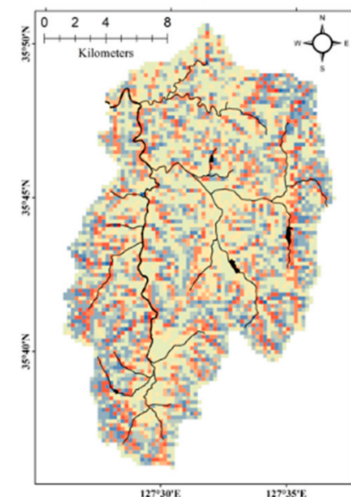

(d)

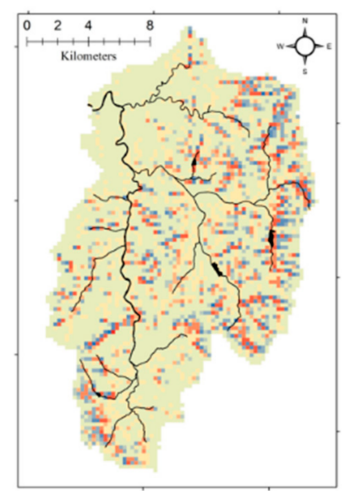

(b)

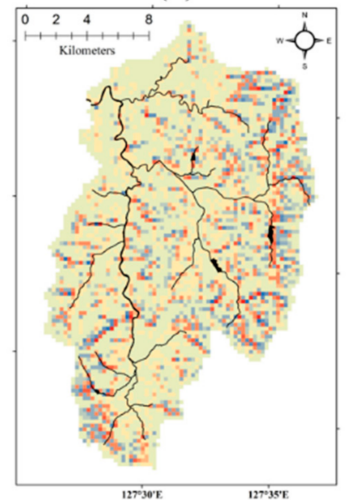

(e)

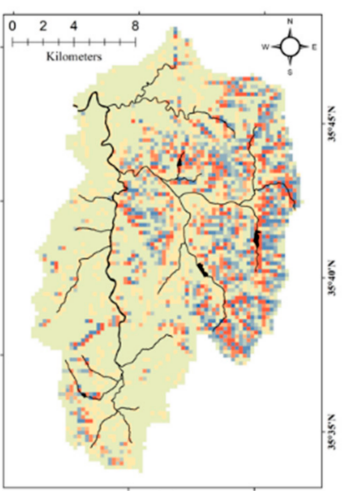

(c)

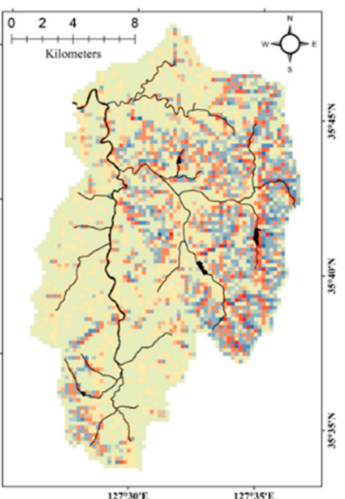

(f)

Figure 6. Spatial-temporal distribution of erosion/deposition maps predicted by the KR method in Event 1 (a), Event 2 (b), and Event 3 (c); and by the EH method in Event 1 (d), Event 2 (e), and Event 3 (f). 
Overall, erosion is more prevalent than deposition, which only accounted for approximately one-third of the basin area shown in the stacked column charts (Figure 7). In Event 1 , the percentage of soil erosion simulated by the KR method was $66.0 \%$ (approximately $174.1 \mathrm{~km}^{2}$ ). After 5 years, this percentage increased to $71.8 \%$ (approximately $208.9 \mathrm{~km}^{2}$ ). This assumedly climate-change-related trend $[67,68]$ has also been validated by results produced by the EH method. The values are $64.1 \%$ and $67.3 \%$, respectively. The percentage of basin area that impacts soil erosion with magnitude ranging from 0.0 to $0.05 \mathrm{~cm}$ is approximately $30-60 \%$. The values for soil deposition are lower, approximately $15-20 \%$. Both soil erosion and deposition with a magnitude higher than $0.5 \mathrm{~cm}$ only account for less than $10 \%$ of the basin area. This concluded that the soil loss in the Cheoncheon basin is mild and in compromise with previous results of Yu et al. [69]. Since the Cheoncheon watershed was mainly covered by forests (approximately 63\%), the rainfall kinetic energy rainfall impacts could be partly precluded by the canopy from directly contacting the land surface [70], and this may reduce the magnitude of soil erosion. The proportions of erosion in 2002 and 2007 were $64.1 \%$ and $67.3 \%$, respectively.

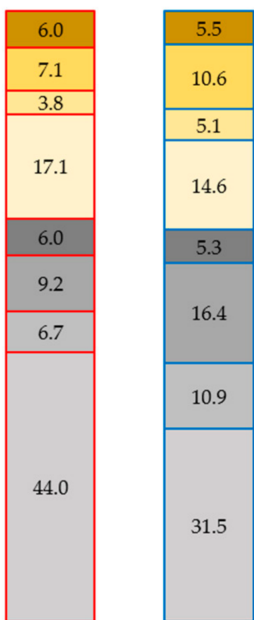

Event 1

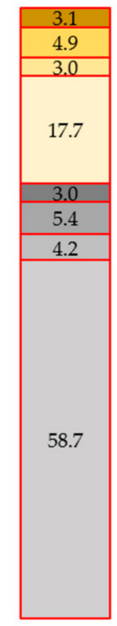

Event 2

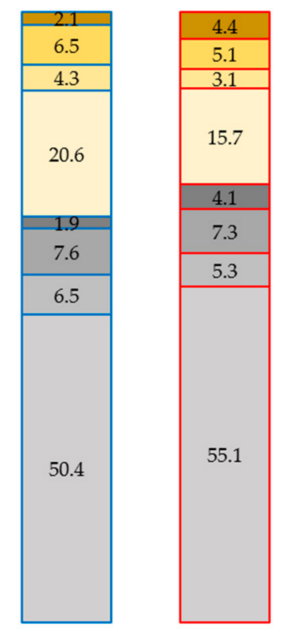

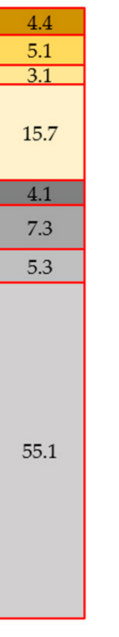

Event 3
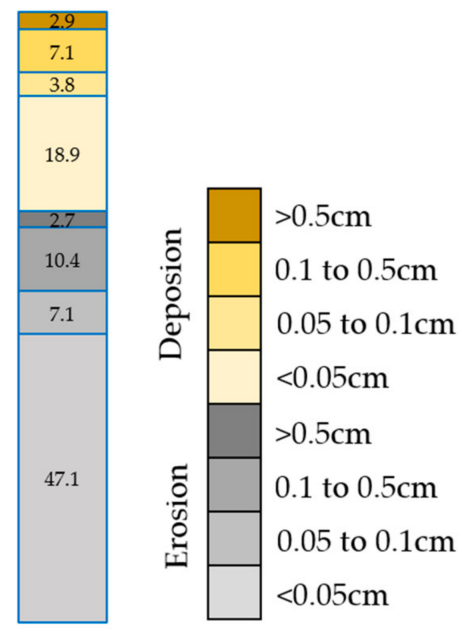

Figure 7. Area of erosion/deposition (in \%) corresponding to various magnitudes predicted by the KR method (in red) and the EH method (in blue).

\subsection{Effect of Topography on Spatial Distribution}

The LULC, soil type, topography, rainfall, and lithology of the bedrock are the main components affecting soil erosion. However, the topography is of significant influence on soil loss [71]. In Figure 8, slope gradients greater than $15^{\circ}$ were prone to cause erosion. The augment in slope gradient triggered overland flow velocity and accelerated the transport capacity at these sites [72]. The eroded particles carried by surface runoff were getting weaker and then deposited on evener and flatter sites with slope gradients ranging from $0-5^{\circ}$. The moderate-slope areas $\left(5-15^{\circ}\right)$ considering both erosion and deposition values corresponded to transition sites. These findings are consistent with the previous study of Busacca et al. [73].

Figure 9 reveals the relationship between land-use type and slope gradient. Locations of forest and pasture higher than the remaining land-use type were more strongly related to soil erosion. The box-whisker plots also show that the EH method had a higher influence on topography than the KR method in soil loss spatial distribution, even though both methods had the same results in sediment concentration prediction. 


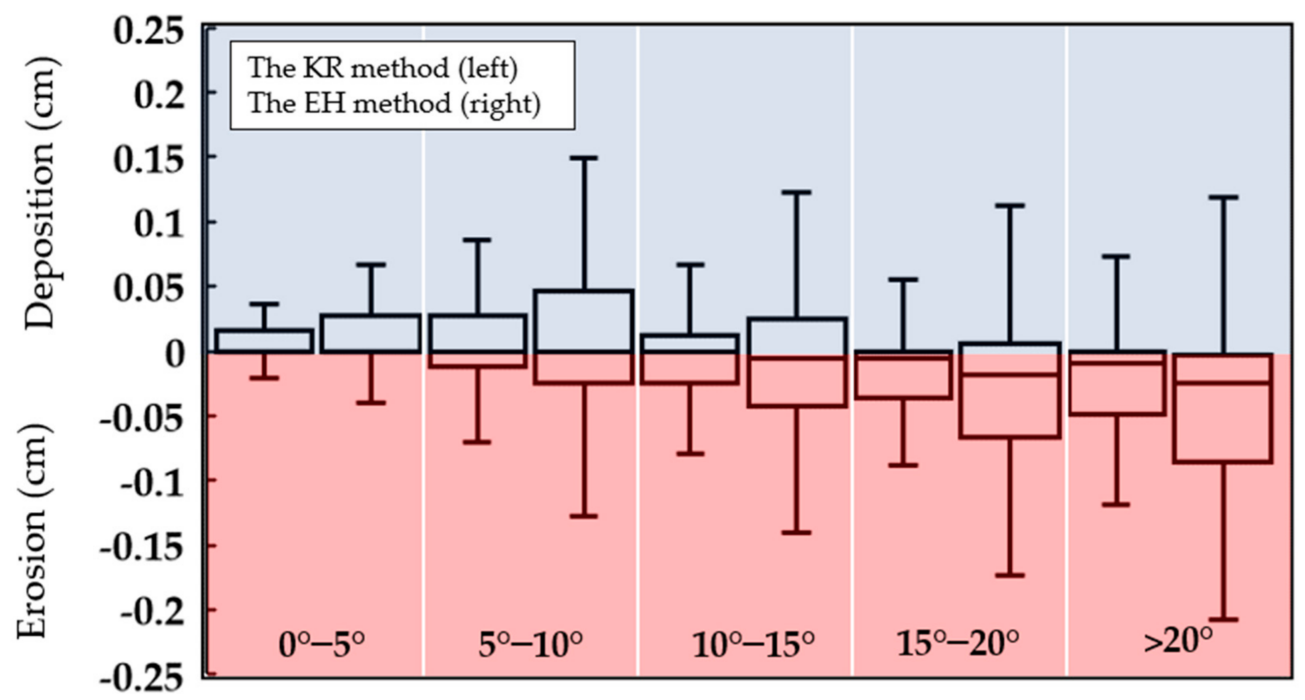

Figure 8. Boxplots of slope gradients show erosion/deposition behavior in three events. In each boxplot, the central line is the median, whereas the edges of the boxes denote the 25 th and 75 th percentiles, respectively. The upper and lower whiskers denote the maximum and minimum, respectively.

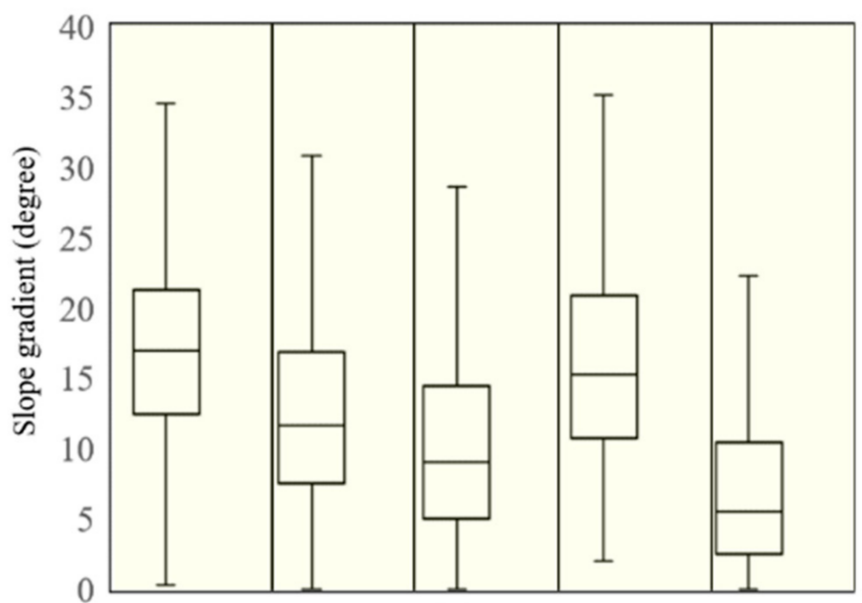

(a)

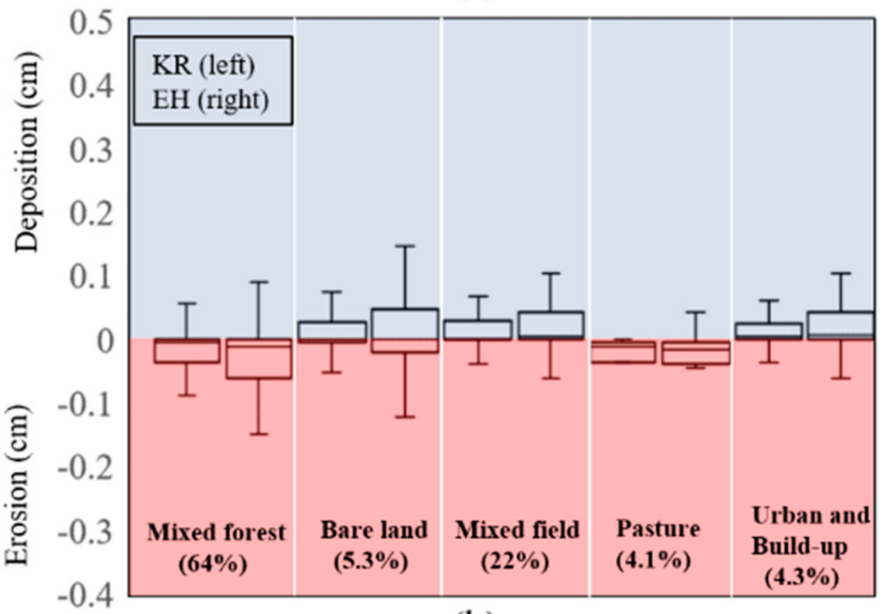

(b)

Figure 9. The interrelation between slope gradient (a) and land-use type (b) toward soil erosion/deposition in three events is demonstrated by boxplots. 
Besides the effect of topography, crop and vegetation stems also affected deposition, notably in agricultural areas. In this watershed, cultivated areas are predominantly located on two sides of rivers. Vegetation stems are instigators that intercept runoff and trap sediment particles [3,27]. Thus, crop stems could contribute a significant influence on the performance of the STC in surface conditions and increase the deposition status of the soil. The spatial distribution patterns of soil organic carbon (SOC) in the watershed (Figure 3d) also indicated that dense SOC content was distinguishable from where the deposition was located. This result is consistent with the study of Zhu et al. [74].

\section{Conclusions}

In this research, the GSSHA model was deployed to evaluate the rainfall-sedimentrunoff process in the Cheoncheon river basin. It is demonstrated that it is possible to reproduce flow discharge over three storm events. Six STC methods were analyzed for simulating sediment concentrations. The principal outcomes are compiled as follows:

(1) From this study, none of the Everaert methods achieved satisfactory results to predict sediment concentrations in three storm events. By allowing the adjustment of an additional parameter, the KR and EH methods surpassed the Everaert methods by producing more accurate results. The KR method also proved to be superior to the EH method when it showed a better performance for sediment concentration simulations with a wide range of sediment size and forcing magnitude.

(2) The spatial distribution of erosion/deposition outputs predicted by the KR and $\mathrm{EH}$ methods had similar patterns. While eroded sites were distributed over the watershed, deposited areas were spotted around streams and water bodies. The EH method illustrated the influence of topography on the distribution of erosion/deposition more significantly than the KR method. The results also indicated that the magnitude of soil loss is mild. Slope gradient was the factor spatially contributing to the soil loss distribution. Results depicted that areas with slope gradients ranging from $0^{\circ}-5^{\circ}$ were prone to be deposited. By contrast, erosion was likely to happen with a slope gradient higher than $15^{\circ}$.

The KR method has a simple structure, allowing developers to apply it to their models, whereas the EH method is the only available option for sediment concentration simulations with specific gravity values of particles different from 2.65. However, it is worth noting that applying the EH equation to STC in specific overland-flow areas should be scrutinized conscientiously owing to the divergence in the original establishment of the equation, such as slope gradients and surface conditions. The constraint in the range of sediment sizes and slope gradients contributed to poor performances of the Everaert methods. These formulas could be suited for mild slope areas.

There were some limitations in this study. Firstly, sampling sediment directly in rivers or reservoirs is the most trendy and preferred approach to measure sediment loads with high accuracy. It is not always feasible during extreme storm events due to safety policy and the difficulty of executing such a task. The absence of sediment data has motivated the deployment of sediment rating curves. Nevertheless, such a method is associated with a significant lack of accuracy in extracting sediment loads from flow discharge [75]. Secondly, initial soil moisture values have a significant impact on the results of rainfallrunoff simulation [76]. The wet conditions of soil trigger the overestimation of soil loss, whereas the soil's dry status leads to the underestimation of sediment concentration for physics-based models [77]. The initial soil moisture data partly affected the results since soil moisture data in this study was provided from the literature. Continuous monitoring of sediment and soil moisture installation is thus essential to reduce data uncertainty and enhance proper evaluation of STC methods since observed datasets of spatial erosion/deposition distribution are excluded in this study.

Soil loss is a worldwide concern contributing to the deterioration of agricultural productivity and water quality. The comprehensive analyses presented above could provide pieces of useful knowledge for choosing an appropriate STC approach to estimate 
soil erosion/deposition at watershed scales. This can be used as a reference to land-use decision-making and to the design of hydraulic installations for soil conservation.

Author Contributions: Methodology, L.N.V. and G.L.; data curation, M.Y. and S.J.; writing—original draft preparation, L.N.V.; writing-review and editing, L.N.V., X.-H.L. and G.V.N.; supervision, G.L. All authors have read and agreed to the published version of the manuscript.

Funding: This subject is supported by Korea Ministry of Environment as "The SS projects; 2019002830001".

Institutional Review Board Statement: Not applicable.

Informed Consent Statement: Not applicable.

Data Availability Statement: Data presented in this study are available in Section 2.

Conflicts of Interest: The authors declare no conflict of interest.

\section{Appendix A}

Table A1. Regression equations for flow and sediment discharge: $\mathrm{H}$ (water level); $\mathrm{Q}$ (river flow); $\mathrm{Q}_{\mathrm{s}}$ (sediment concentration).

\begin{tabular}{ccc}
\hline Event no. & Rating Curve Equation & Discharge-Sediment Loads Equation \\
\hline 1 & $\mathrm{Q}=24.945 \times(\mathrm{H}-2.281)^{2.448}$ & $\mathrm{Q}_{\mathrm{s}}=9 \times 10^{-6}-5 \times \mathrm{Q}^{1.700}$ \\
2 & $\mathrm{Q}=53.522 \times(\mathrm{H}-2.346)^{2.219}$ & $\mathrm{Q}_{\mathrm{s}}=5 \times 10^{-7}-6 \times \mathrm{Q}^{1.932}$ \\
3 & $\mathrm{Q}=50.403 \times(\mathrm{H}-2.367)^{2.257}$ & $\mathrm{Q}_{\mathrm{s}}=28 \times 10^{-7}-5 \times \mathrm{Q}^{1.818}$ \\
\hline
\end{tabular}

Table A2. Particle size distributions (\%) in the Cheoncheon basin.

\begin{tabular}{|c|c|c|c|c|c|c|c|c|}
\hline \multirow{3}{*}{ Soil Type } & \multicolumn{5}{|c|}{ Sand } & \multicolumn{2}{|c|}{ Silt } & \multirow[t]{2}{*}{ Clay } \\
\hline & Very Coarse & Coarse & Medium & Fine & Very Fine & Coarse & Fine & \\
\hline & $2.0-1.0 \mathrm{~mm}$ & $1.0-0.5$ & $0.5-0.25$ & $0.25-0.1$ & $0.1-0.05$ & $0.05-0.02$ & $0.02-0.002$ & $0.002-0.0002$ \\
\hline Anryong & 2.7 & 5.8 & 5.2 & 5.7 & 3.1 & 36.2 & 13.2 & 28.2 \\
\hline Chilgog & 6.7 & 9 & 7.4 & 6.9 & 3.8 & 23.2 & 19.4 & 23.6 \\
\hline Deogpyeong & 2.6 & 4.8 & 4.1 & 3.4 & 4.3 & 20 & 25 & 35.9 \\
\hline Deogsan & 7.3 & 9.1 & 11.4 & 16.1 & 7.8 & 10.5 & 22.5 & 15.3 \\
\hline Eungog & 15.5 & 21.7 & 15.3 & 12.5 & 5.8 & 9.5 & 10.1 & 9.8 \\
\hline Gacheon & 6.8 & 14.3 & 19.9 & 19.4 & 9.9 & 10 & 12.8 & 7 \\
\hline Gopyeong & 0.5 & 1.1 & 1.1 & 1.5 & 1.1 & 47.4 & 9 & 38.2 \\
\hline Gwanag & 19.6 & 12.5 & 9.4 & 8.3 & 9.5 & 15 & 16.5 & 9.3 \\
\hline Hamo & 3.4 & 4.4 & 5.4 & 8.7 & 4.5 & 20 & 30.7 & 23 \\
\hline Hoegog & 7.5 & 14.2 & 15.1 & 15.3 & 6.8 & 13.1 & 17.4 & 10.6 \\
\hline Hogye & 4.7 & 8.2 & 5.9 & 1.8 & 10.9 & 21 & 18.1 & 29.4 \\
\hline Hwadong & 1.4 & 2.9 & 1.2 & 0.8 & 1.9 & 30 & 27.9 & 34 \\
\hline Hwangryong & 1.4 & 6 & 20.8 & 45.8 & 11.7 & 3.5 & 8.4 & 2.5 \\
\hline Imgog & 2 & 4.3 & 5.9 & 8.9 & 7 & 21.9 & 23.7 & 26.4 \\
\hline Janggye & 3.7 & 7.3 & 10.4 & 16.7 & 11.3 & 13.4 & 20.1 & 17.1 \\
\hline Jigog & 11.2 & 15.6 & 12.9 & 12.2 & 5.2 & 13.5 & 15.2 & 14.3 \\
\hline Maegog & 9.4 & 20.1 & 16.9 & 12.9 & 11.3 & 9.7 & 13.1 & 6.6 \\
\hline Namgye & 17.7 & 19.4 & 15.7 & 15.9 & 5.2 & 9.2 & 7.7 & 9.1 \\
\hline Odae & 25 & 18.3 & 6.9 & 6.3 & 6.1 & 17.2 & 4.6 & 15.4 \\
\hline
\end{tabular}


Table A2. Cont.

\begin{tabular}{|c|c|c|c|c|c|c|c|c|}
\hline \multirow{3}{*}{ Soil Type } & \multicolumn{5}{|c|}{ Sand } & \multicolumn{2}{|c|}{ Silt } & \multirow[t]{2}{*}{ Clay } \\
\hline & Very Coarse & Coarse & Medium & Fine & Very Fine & Coarse & Fine & \\
\hline & $2.0-1.0 \mathrm{~mm}$ & $1.0-0.5$ & $0.5-0.25$ & $0.25-0.1$ & $0.1-0.05$ & $0.05-0.02$ & $0.02-0.002$ & $0.002-0.0002$ \\
\hline Oesan & 5.9 & 7.3 & 4.2 & 4 & 2.4 & 28 & 27.4 & 20.8 \\
\hline Osan & 5 & 11 & 0.1 & 9 & 5.2 & 28.9 & 24.6 & 16.2 \\
\hline Pungcheon & 6.5 & 12.6 & 14.3 & 14 & 6.6 & 15.4 & 14.8 & 15.8 \\
\hline Rcs & 6.7 & 9 & 7.4 & 6.9 & 3.8 & 23.2 & 19.4 & 23.6 \\
\hline Rock outcrop & 0.5 & 1.1 & 1.1 & 1.5 & 1.1 & 47.4 & 9 & 38.2 \\
\hline Sachon & 4.9 & 12.9 & 18.5 & 15.4 & 9.1 & 15.3 & 11.4 & 12.4 \\
\hline Samam & 4.2 & 7.4 & 7.8 & 9 & 6.8 & 24.3 & 22.3 & 18.3 \\
\hline Samgag & 16.4 & 17.3 & 13.1 & 6.9 & 6.9 & 11 & 13.9 & 14.6 \\
\hline Sangju & 13.8 & 22.9 & 21.9 & 12.4 & 5.5 & 7.9 & 6.6 & 9 \\
\hline Seogto & 3.8 & 5.3 & 3.7 & 3.4 & 1.9 & 31.6 & 23.4 & 27 \\
\hline Seongin & 4.4 & 9.3 & 11.5 & 6.8 & 3.5 & 25.5 & 17 & 22.1 \\
\hline Songsan & 9.8 & 18.6 & 15.1 & 12.3 & 5 & 10.6 & 11.1 & 17.6 \\
\hline Suam & 7.5 & 10.6 & 16.8 & 22.8 & 14.9 & 10 & 10.6 & 6.9 \\
\hline Ugog & 3.6 & 3.3 & 1.5 & 0.3 & 5.5 & 25 & 30 & 30.9 \\
\hline Water & 2 & 4.3 & 5.9 & 8.9 & 7 & 21.9 & 23.7 & 26.4 \\
\hline Weolgog & 15.5 & 21.7 & 15.3 & 12.5 & 5.8 & 9.5 & 10.1 & 9.8 \\
\hline Yecheon & 15.9 & 16.6 & 10.8 & 10.3 & 5.8 & 14.5 & 11.8 & 14.5 \\
\hline Yesan & 9.7 & 17.4 & 15.3 & 13 & 5.4 & 8.8 & 12.3 & 18 \\
\hline Yonggye & 5.7 & 7.9 & 6.8 & 6.5 & 3.9 & 22 & 21.7 & 25.6 \\
\hline
\end{tabular}

\section{References}

1. Foster, G.G. The Use of Bridging Systems to Increase Genetic Variability in Compound Chromosome Strains for Genetic Control of Lucilia Cuprina (Wiedemann). Theor. Appl. Genet. 1982, 63, 295-305. [CrossRef] [PubMed]

2. Li, G.; Abrahams, A.D. Controls of Sediment Transport Capacity in Laminar Interrill Flow on Stone-Covered Surfaces. Water Resour. Res. 1999, 35, 305-310. [CrossRef]

3. $\mathrm{Mu}, \mathrm{H} . ; \mathrm{Yu}, \mathrm{X}$; Fu, S.; Yu, B.; Liu, Y.; Zhang, G. Effect of Stem Basal Cover on the Sediment Transport Capacity of Overland Flows Geoderma 2019, 337, 384-393. [CrossRef]

4. Lindström, G.; Pers, C.; Rosberg, J.; Strömqvist, J.; Arheimer, B. Development and Testing of the HYPE (Hydrological Predictions for the Environment) Water Quality Model for Different Spatial Scales. Hydrol. Res. 2010, 41, 295-319. [CrossRef]

5. $\quad$ Morgan, R.P.C.; Quinton, J.N.; Smith, R.E.; Govers, G.; Poesen, J.W.A.; Auerswald, K.; Chisci, G.; Torri, D.; Styczen, M.E. The European Soil Erosion Model (EUROSEM): A Dynamic Approach for Predicting Sediment Transport from Fields and Small Catchments. Earth Surf. Process. Landf. 1998, 23, 527-544. [CrossRef]

6. Von Werner, M. Erosion-3D: User Manual, Version. 3.1.1 2006; Geognostics: Berlin, Germany, 2006.

7. Ewen, J.; Parkin, G.; O'Connell, P.E. SHETRAN: Distributed River Basin Flow and Transport Modeling System. J. Hydrol. Eng. 2000, 5, 250-258. [CrossRef]

8. USDA-ARS. Revised Universal Soil Loss Equation Version 2 (RUSLE2); (For the Model with Release Date of 20 May 2008); Agricultural Research Service: Washington, DC, USA, 2013.

9. APIP; Lee, G.; Yu, W.; Jung, K. Catchment-Scale Soil Erosion and Sediment Yield Simulation Using a Spatially Distributed Erosion Model. Env. Earth Sci. 2013, 70, 33-47. [CrossRef]

10. Wang, S.; Flanagan, D.C.; Engel, B.A. Estimating Sediment Transport Capacity for Overland Flow. J. Hydrol. 2019, $578,123985$. [CrossRef]

11. Ali, M.; Seeger, M.; Sterk, G.; Moore, D. A Unit Stream Power Based Sediment Transport Function for Overland Flow. Catena 2013, 101, 197-204. [CrossRef]

12. Ali, M.; Sterk, G.; Seeger, M.; Boersema, M.; Peters, P. Effect of Hydraulic Parameters on Sediment Transport Capacity in Overland Flow over Erodible Beds. Hydrol. Earth Syst. Sci. 2012, 16, 591-601. [CrossRef] 
13. Zhang, G.; Liu, Y.; Han, Y.; Zhang, X.C. Sediment Transport and Soil Detachment on Steep Slopes: I. Transport Capacity Estimation. Soil Sci. Soc. Am. J. 2009, 73, 1291-1297. [CrossRef]

14. Abrahams, A.D.; Li, G.; Krishnan, C.; Atkinson, J.F. A Sediment Transport Equation for Interrill Overland Flow on Rough Surfaces. Earth Surf. Process. Landf. 2001, 26, 1443-1459. [CrossRef]

15. Wang, Z.; Yang, X.; Liu, J.; Yuan, Y. Sediment Transport Capacity and Its Response to Hydraulic Parameters in Experimental Rill Flow on Steep Slope. J. Soil Water Conserv. 2015, 70, 36-44. [CrossRef]

16. Prosser, I.P.; Rustomji, P. Sediment Transport Capacity Relations for Overland Flow. Prog. Phys. Geogr. Earth Environ. 2000, 24, 179-193. [CrossRef]

17. Everaert, W. Empirical Relations for the Sediment Transport Capacity of Interrill Flow. Earth Surf. Process. Landf. 1991, 16, 513-532. [CrossRef]

18. Guy, B.T.; Dickenson, W.T.; Sohrabi, T.M.; Rudra, R.P. Development of an Empirical Model for Calculating Sediment-Transport Capacity in Shallow Overland Flows: Model Calibration. Biosyst. Eng. 2009, 103, 245-255. [CrossRef]

19. Guy, B.T.; Rudra, R.P.; Dickenson, W.T.; Sohrabi, T.M. Empirical Model for Calculating Sediment-Transport Capacity in Shallow Overland Flows: Model Development. Biosyst. Eng. 2009, 103, 105-115. [CrossRef]

20. Zhang, G.-H.; Wang, L.-L.; Tang, K.-M.; Luo, R.-T.; Zhang, X.C. Effects of Sediment Size on Transport Capacity of Overland Flow on Steep Slopes. Hydrol. Sci. J. 2011, 56, 1289-1299. [CrossRef]

21. Ni, S.; Feng, S.; Zhang, D.; Wang, J.; Cai, C. Sediment Transport Capacity in Erodible Beds with Reconstituted Soils of Different Textures. Catena 2019, 183, 104197. [CrossRef]

22. Yu, B.; Zhang, G.; Fu, X. Transport Capacity of Overland Flow with High Sediment Concentration. J. Hydrol. Eng. 2015, 20, C4014001. [CrossRef]

23. Zhang, G.H.; Wang, L.L.; Li, G.; Tang, K.M.; Cao, Y. Relationship between Sediment Particle Size and Transport Coefficient on Steep Slopes. Trans. ASABE 2011, 54, 869-874. [CrossRef]

24. Zhan, Z.; Jiang, F.; Chen, P.; Gao, P.; Lin, J.; Ge, H.; Wang, M.K.; Huang, Y. Effect of Gravel Content on the Sediment Transport Capacity of Overland Flow. Catena 2020, 188, 104447. [CrossRef]

25. Zhang, P.; Yao, W.; Liu, G.; Xiao, P.; Sun, W. Experimental Study of Sediment Transport Processes and Size Selectivity of Eroded Sediment on Steep Pisha Sandstone Slopes. Geomorphology 2020, 363, 107211. [CrossRef]

26. Gabet, E.J.; Sternberg, P. The Effects of Vegetative Ash on Infiltration Capacity, Sediment Transport, and the Generation of Progressively Bulked Debris Flows. Geomorphology 2008, 101, 666-673. [CrossRef]

27. Pan, C.; Ma, L.; Shangguan, Z. Effectiveness of Grass Strips in Trapping Suspended Sediments from Runoff. Earth Surf. Process. Landf. 2010, 35, 1006-1013. [CrossRef]

28. Englelund, F.; Hansen, E. A Monograph on Sediment Transport in Alluvial Streams; Teknisk Forlag: Copenhagen, Denmark, 1967; p. 65.

29. Yalin, M.S. An Expression for Bed-Load Transportation. J. Hydraul. Div. 1963, 89, 221-250. [CrossRef]

30. Smart, G.M. Sediment Transport Formula for Steep Channels. J. Hydraul. Eng. 1984, 110, 267-276. [CrossRef]

31. Seng Low, H. Effect of Sediment Density on Bed-Load Transport. J. Hydraul. Eng. 1989, 115, 124-138. [CrossRef]

32. Hessel, R.; Jetten, V. Suitability of Transport Equations in Modelling Soil Erosion for a Small Loess Plateau Catchment. Eng. Geol. 2007, 91, 56-71. [CrossRef]

33. Kilinc, M.; Richardson, E.V. Mechanics of Soil Erosion From Overland Flow Generated; Colorado State University: Fort Colins, CO, USA, 1973; p. 61.

34. Guy, B.T.; Dickinson, W.T.; Rudra, R.P. Evaluation of Fluvial Sediment Transport Equations for Overland Flow. Trans. ASAE 1992, 35, 545-555. [CrossRef]

35. Yang, C.T. Unit Stream Power and Sediment Transport. J. Hydraul. Div. 1972, 98, 1805-1826. [CrossRef]

36. Govers, G. Empirical Relationships on the Transporting Capacity of Overland Flow. In Transport and Deposition Processes (Proceedings of the Jerusalem Workshop, March-April 1987); IAHS Press: Wallingford, UK, 1990; Volume 189, pp. 45-63.

37. Downer, C.W.; Pradhan, N.R.; Ogden, F.L.; Byrd, A.R. Testing the Effects of Detachment Limits and Transport Capacity Formulation on Sediment Runoff Predictions Using the U.S. Army Corps of Engineers GSSHA Model. J. Hydrol. Eng. 2015, 20, 04014082. [CrossRef]

38. Sith, R.; Nadaoka, K. Comparison of SWAT and GSSHA for High Time Resolution Prediction of Stream Flow and Sediment Concentration in a Small Agricultural Watershed. Hydrology 2017, 4, 27. [CrossRef]

39. Ogden, F.L. Evidence of Equilibrium Peak Runoff Rates in Steep Tropical Terrain on the Island of Dominica during Tropical Storm Erika, 27 August 2015. J. Hydrol. 2016, 542, 35-46. [CrossRef]

40. Pradhan, N.R.; Loney, D. An Analysis of the Unit Hydrograph Peaking Factor: A Case Study in Goose Creek Watershed, Virginia. J. Hydrol. Reg. Stud. 2018, 15, 31-48. [CrossRef]

41. Saha, G.C.; Li, J.; Thring, R.W.; Hirshfield, F.; Paul, S.S. Temporal Dynamics of Groundwater-Surface Water Interaction under the Effects of Climate Change: A Case Study in the Kiskatinaw River Watershed, Canada. J. Hydrol. 2017, 551, 440-452. [CrossRef]

42. Hur, J.; Jung, N.-C.; Shin, J.-K. Spectroscopic Distribution of Dissolved Organic Matter in a Dam Reservoir Impacted by Turbid Storm Runoff. Environ. Monit Assess 2007, 133, 53-67. [CrossRef]

43. Hong, S.Y.; Zhang, Y.-S.; Hyun, B.-K.; Sonn, Y.-K.; Kim, Y.-H.; Jung, S.-J.; Park, C.-W.; Song, K.-C.; Jang, B.-C.; Choe, E.-Y.; et al. An Introduction of Korean Soil Information System. Korean J. Soil Sci. Fertil. 2009, 42, 21-28. 
44. USDA. Soil Taxonomy: A Basic System of Soil Classification for Making and Interpreting Soil Surveys; USDA: Washington, DC, USA, 1999.

45. Sastre, B.; Barbero-Sierra, C.; Bienes, R.; Marques, M.J.; García-Díaz, A. Soil Loss in an Olive Grove in Central Spain under Cover Crops and Tillage Treatments, and Farmer Perceptions. J Soils Sediments 2017, 17, 873-888. [CrossRef]

46. K-Water. Hydrological Investigation Report of Yongdam Dam Basin; Korean Water and Wastewater Association: Seoul, Korea, 2002.

47. K-Water. Hydrological Investigation Report of Yongdam Dam Basin; Korean Water and Wastewater Association: Seoul, Korea, 2003.

48. K-Water. Hydrological Investigation Report of Yongdam Dam Basin; Korean Water and Wastewater Association: Seoul, Korea, 2007.

49. Julien, P.Y. Erosion and Sedimentation; Cambridge University Press: Cambridge, UK, 1995.

50. Ogden, F.; Heilig, A. Two-Dimensional Watershed-Scale Erosion Modeling With CASC2D. In Landscape Erosion and Evolution Modeling; Harmon, R.S., Doe, W.W., Eds.; Springer US: Boston, MA, USA, 2001; pp. 277-320. ISBN 978-1-4613-5139-9.

51. Downer, C.W.; Ogden, F.L. GSSHA: Model To Simulate Diverse Stream Flow Producing Processes. J. Hydrol. Eng. 2004, 9, 161-174. [CrossRef]

52. The Complete All-in-one Watershed Solution. Available online: https://www.aquaveo.com/software/wms-watershedmodeling-system-introduction (accessed on 8 July 2021).

53. Wicks, J.M.; Bathurst, J.C. SHESED: A Physically Based, Distributed Erosion and Sediment Yield Component for the SHE Hydrological Modelling System. J. Hydrol. 1996, 175, 213-238. [CrossRef]

54. Capra, A.; Porto, P.; Scicolone, B. Relationships between Rainfall Characteristics and Ephemeral Gully Erosion in a Cultivated Catchment in Sicily (Italy). Soil Tillage Res. 2009, 105, 77-87. [CrossRef]

55. ESRI. ESRI Data and Maps for ArcGIS; Environmental Systems Research Institute: Redlands, CA, USA, 2021.

56. Lee, G.; Tachikawa, Y.; Takara, K. Interaction between Topographic and Process Parameters Due to the Spatial Resolution of DEMs in Distributed Rainfall-Runoff Modeling. J. Hydrol. Eng. 2009, 14, 1059-1069. [CrossRef]

57. Duan, Q.Y.; Gupta, V.K.; Sorooshian, S. Shuffled Complex Evolution Approach for Effective and Efficient Global Minimization. J. Optim. Theory Appl. 1993, 76, 501-521. [CrossRef]

58. Downer, C.W.; Ogden, F.L. Gridded Surface Subsurface Hydrologic Analysis (GSSHA) User's Manual; U.S. Army Corps of Engineers: Washington, DC, USA, 2006.

59. Gupta, H.V.; Sorooshian, S.; Yapo, P.O. Status of Automatic Calibration for Hydrologic Models: Comparison with Multilevel Expert Calibration. J. Hydrol. Eng. 1999, 4, 135-143. [CrossRef]

60. Du, J.; Xie, S.; Xu, Y.; Xu, C.; Singh, V.P. Development and Testing of a Simple Physically-Based Distributed Rainfall-Runoff Model for Storm Runoff Simulation in Humid Forested Basins. J. Hydrol. 2007, 336, 334-346. [CrossRef]

61. Johnson, B.E.; Julien, P.Y.; Molnar, D.K.; Watson, C.C. The two-dimensional upland erosion model CASC2D-SED. J. Am. Water Resour. Assoc. 2000, 36, 31-42. [CrossRef]

62. Lei, T.W.; Zhang, Q.; Zhao, J.; Tang, Z. A Laboratory Study of Sediment Transport Capacity in the Dynamic Process of Rill Erosion. Trans. Am. Soc. Agric. Eng. 2001, 44, 1537-1542.

63. Xiao, H.; Liu, G.; Liu, P.; Zheng, F.; Zhang, J.; Hu, F. Sediment Transport Capacity of Concentrated Flows on Steep Loessial Slope with Erodible Beds. Sci. Rep. 2017, 7, 1-9. [CrossRef] [PubMed]

64. Zhang, F.B.; Yang, M.Y.; Li, B.B.; Li, Z.B.; Shi, W.Y. Effects of Slope Gradient on Hydro-Erosional Processes on an Aeolian Sand-Covered Loess Slope under Simulated Rainfall. J. Hydrol. 2017, 553, 447-456. [CrossRef]

65. Lu, J.Y.; Cassol, E.A.; Moldenhauer, W.C. Sediment Transport Relationships for Sand and Silt Loam Soils. Trans. ASAE 1989, 32, 1923. [CrossRef]

66. Alonso, C.V.; Neibling, W.H.; Foster, G.R. Estimating Sediment Transport Capacity in Watershed Modeling. Trans. ASAE 1981, 24, 1211-1220. [CrossRef]

67. Chen, C.-N.; Tfwala, S.S.; Tsai, C.-H. Climate Change Impacts on Soil Erosion and Sediment Yield in a Watershed. Water 2020, 12, 2247. [CrossRef]

68. Routschek, A.; Schmidt, J.; Kreienkamp, F. Impact of Climate Change on Soil Erosion-A High-Resolution Projection on Catchment Scale until 2100 in Saxony/Germany. Catena 2014, 121, 99-109. [CrossRef]

69. Yu, W.; Lee, G.; Kim, Y.; Jung, K. Watershed-Based PMF and Sediment-Runoff Estimation Using Distributed Hydrological Model. J. Korean Soc. Agric. Eng. 2018, 60, 1-11.

70. Li, G.; Wan, L.; Cui, M.; Wu, B.; Zhou, J. Influence of Canopy Interception and Rainfall Kinetic Energy on Soil Erosion under Forests. Forests 2019, 10, 509. [CrossRef]

71. Wu, L.; Peng, M.; Qiao, S.; Ma, X. Effects of Rainfall Intensity and Slope Gradient on Runoff and Sediment Yield Characteristics of Bare Loess Soil. Environ. Sci. Pollut. Res. 2018, 25, 3480-3487. [CrossRef] [PubMed]

72. Fox, D.M.; Bryan, R.B. The Relationship of Soil Loss by Interrill Erosion to Slope Gradient. Catena 2000, 38, 211-222. [CrossRef]

73. Busacca, A.J.; Cook, C.A.; Mulla, D.J. Comparing Landscape-Scale Estimation of Soil Erosion in the Palouse Using Cs-137 and RUSLE. J. Soil Water Conserv. 1993, 48, 361-367.

74. Zhu, Y.; Wang, D.; Wang, X.; Li, W.; Shi, P. Aggregate-Associated Soil Organic Carbon Dynamics as Affected by Erosion and Deposition along Contrasting Hillslopes in the Chinese Corn Belt. Catena 2021, 199, 105106. [CrossRef]

75. Walling, D.E.; Webb, B.W. The Reliability of Rating Curve Estimates of Suspended Sediment Yield: Some Further Comments. In Proceedings of the Symposium on Sediment Budgets, Porto Alegre, Brazil, 11-15 December 1988. 
76. Zehe, E.; Becker, R.; Bárdossy, A.; Plate, E. Uncertainty of Simulated Catchment Runoff Response in the Presence of Threshold Processes: Role of Initial Soil Moisture and Precipitation. J. Hydrol. 2005, 1-4, 183-202. [CrossRef]

77. Ahmadi, S.H.; Amin, S.; Reza Keshavarzi, A.; Mirzamostafa, N. Simulating Watershed Outlet Sediment Concentration Using the ANSWERS Model by Applying Two Sediment Transport Capacity Equations. Biosyst. Eng. 2006, 94, 615-626. [CrossRef] 